\title{
Impact of Bali Cattle Calf Marketing to the Farmers Income
}

\author{
Ni Made Ayu Gemuh Rasa Astiti ${ }^{1 *}$ \\ ${ }^{* 1}$ Warmadewa University, Denpasar, Indonesia. \\ 1*ayugemuh@gmail.com
}

\begin{abstract}
.
The purpose of this study was to determine the marketing of Balinese calves that provide optimal income for farmers. This research is using explorative methods through survey. This research was conducted on the marketing of Balinese calves as well as animal markets and intermediary traders spread across Badung Regency. The research location was chosen deliberately (purposive sampling). The results of this study indicate that there are four channels formed by the calf marketing system in Bali, namely marketing channel I (breeder to other breeders 12\%), marketing channel II (breeder-animal market-intermediary trader 10\%), marketing channel III (breeder-intermediary traders-animal market 73\%), and channel IV (breedersgroup 5\%). Farmer income from the sale of calves through marketing IV that provides the highest income for both male and female calves is Rp 6,842,500 and Rp 3,717,500. The high marketing profit in channel IV is because the marketing costs are small because every marketing agency that is traversed wants profit, so the longer the marketing chain the higher the marketing margin. The most efficient calf marketing system is channel II, which is $0.25 \%$ because the smaller the efficiency of the marketing institution, the more efficient the marketing institution.
\end{abstract}

Keywords. Bali Cattle Calf, Revenue, Marketing.

Received: 10 August 2019

Accepted: 10 September 2019 


\section{INTRODUCTION}

Efficient marketing will be able to provide higher prices for farmers. Thus, a more efficient marketing system absolutely must be considered, so that cattle ranching can provide additional higher income for farmers. The increase in income will encourage farmers to raise more cattle. In addition, it will encourage breeders to carry out maintenance in a better way, for example, providing higher quality feed, and better mating systems such as the use of artificial insemination (IB), so as to improve the quality of cattle produced [1][11][18].

This will indirectly increase the cattle population in Bali as desired by the government. The success of a cattle breeding business is inseparable from the marketing system, therefore the initial steps of a variety of problems encountered in calf marketing in Bali include: inadequate marketing policies, market structures that tend to lead to monopsony markets, long market chains, smuggling, buying and selling quota for cattle, lack of supervision, in addition to the low entrepreneurial spirit of the farmers [2] [15]. This condition must be improved, so as to be able to improve the welfare of farmers. Calf marketing is done after the product is produced. One alternative done by farmers is to sell through marketing institutions.

The problem faced is the existence of marketing institutions will cause product prices to change after reaching consumers. This is because every marketing institution seeks to perform marketing functions that add to the utility value of an item thereby increasing marketing costs [3][16] the marketing costs are usually charged by marketing institutions to producers or consumers, namely by increasing consumer prices or pressing prices at the level of farmers/calf producers.

\section{MATERials AND Methods}

\section{Research Location}

This research is survey research that was designed as explorative research because it intends to explore deeply about phenomena in the field. This research is a combination of qualitative and quantitative with the main approach used in problem-solving in this research is the quantitative approach. A quantitative approach is a system approach (system approach), which in this approach is in accordance with reality (real system) [4][14][19]. The Bali cattle breeding business and the marketing of Bali cattle calf involve behavioral and institutional aspects that are sometimes difficult to quantify, but these aspects must still be considered. Therefore, besides using a quantitative approach, this research is also equipped with a qualitative approach to enrich the discussion so that this research will be sharper and relevant to the problems in the field.

This research was conducted in the Province of Bali precisely in Badung Regency. The research location was chosen purposively (purposive sampling) based on the consideration that is the largest population of Bali cows among eight regencies and one city that is spread across the island of Bali and which has the potential for 
animal markets and the development of business of mother cows in Bali. This research was conducted from January to June 2018. Data Types and Sources the data used in this study can be distinguished.

\section{Into two namely}

Qualitative data includes 1) respondent characteristics, including age, number of family members, number of parents maintained. 2) Costs and income of farmers and 43 marketing data: age of calf sold, selling price of male and female calf, ideas, views, and problems faced by Bali cattle breeders in Bali, in terms of marketing calf/calf aged 6-8 months, related marketing institutions both in terms of marketing channels/chains.

\section{Quantitative Data}

Quantitative data in the form of the number of Bali cattle breeders in Bali, the number of male and female calf marketed, data on the number of Bali calf production in Bali, the marketing costs incurred in the process of marketing a calf through marketing institutions, the number of marketed calf and the price of male and female calf when research carried out.

\section{Data source}

Primary data obtained from direct observation and conducting interviews with individuals involved using the instrument in the form of a questionnaire or a list of questions prepared previously in accordance with the problems and objectives of this study. Secondary data obtained through documents or company data which includes activities in carrying out marketing of Bali's calf. In addition, secondary data is taken from related institutions and agencies related to this research. Documents sourced from the Central Statistics Agency (BPS) and agencies related to this study are the Animal Husbandry Department [5][13]. Data collection technique Data obtained in this study were collected in four ways, namely direct interviews using structured questionnaires that have been prepared. In-depth interviews (in-depth interview) using a list of open questions as a guide for interviews, observations observing the marketing of Bali calf cattle that have been carried out by farmers and interviews directly to the Atlantic [6][12].

\section{RESULTS AND DISCUSSION}

Based on the results of research that has been done, it was found that the current number of cattle ownership in Bali cattle is 5.02 per respondent breeders, and not all breeders have calves. From the results of data processing it was found that of the 50 respondents had an average male calf of 0.72 while the female calf of 1.02, it was seen that more female calf compared to the number of male calves owned by the respondent, this is very influential on income because the selling price of male Bali calf is more expensive than the selling price of female Bali calf calf. Bali cattle ownership is not the maximum number of breeders' maintenance capabilities. This is supported by the results of research [7][20][22] said that the maximum ability of breeders in maintaining the parent 
is an average of 5.03 brooders with a range of 3 birds (3.41\%), 4 tails (36.36\%), 5 tails (32.95\%), 6 tails (18.18\%), 7 tails (5.68\%) with the same maintenance pattern as has been done so far. Besides that, not all breeders currently have calves only $0.56 \%$ have male calves and $0.96 \%$ have female calves.

\section{Table 1. Number of Respondents' Livestock Ownership}

Source: Data Processing Results

\begin{tabular}{|l|l|l|l|}
\hline Category & type & \multicolumn{2}{|l|}{50 Respondents } \\
\hline Livestock & sex & Amount (Tail) & Average (Tail) \\
\hline Adult & Male & 53 & 1.06 \\
\hline Adult & Female & 111 & 2.22 \\
\hline Calf & Male & 36 & 0.72 \\
\hline Calf & Female & 51 & 1.02 \\
\hline \multicolumn{2}{|l|}{ Total Average } & 251 & 5.02 \\
\hline
\end{tabular}

In managing breeders' farms, they always try to keep the costs spent to a minimum to obtain maximum production so that the business is economically profitable. Increasing profits automatically farmers' income and welfare will increase. Farm income is the profit obtained by farmers from the difference between the costs incurred during the calf marketing process. Farmer income from calf sales depends on the sex of the calf and the number of calf sold and the channels traversed by the calf marketing. Calculation of farmer's income can be done in two ways, namely: in whatever farms the farmer receives from selling calves, it is farmer's income because the farmer never counts the costs incurred during the production process, whether in the form of feed, cage depreciation or labor used. The second calculation by means of an economic calculation. Economic calculations result in our farmers never profit because no matter how small the costs incurred by farmers must be calculated including land rent, use of labor and others [8][17][21].
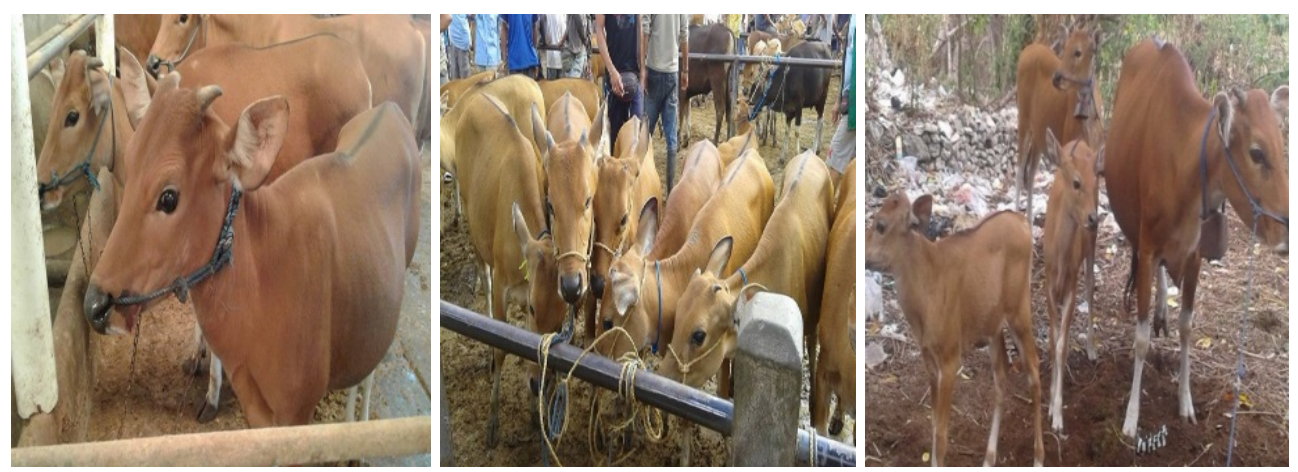

Figure 1. Animal Market in Bali

The difference in the price of the male and female calf is quite high, namely $178.13 \%$, almost double the price of female calf, so that the breeders really expect from the birth of a parent to get a male calf, but the chance 
to get a male calf is only $50 \%$. The high price of male calves is due to the tendency of breeders to maintain male calves because the growth of male calves is faster [9] [18]. In contrast to marketing female calf is only allowed to sell on the island of Bali, so that the availability of female calf is quite a lot, which will result in low female calf price. To increase farmers' income from calf marketing, it is necessary to have government regulations to allow female calf to be sold outside the region so that the female calf market structure can be more perfectly competitive. Farmer income in terms of calf marketing varies. Farmer income from calf sales through marketing IV, which gives the highest income both male and female calf, is Rp 6,842,500 and Rp 3,717,500, as shown in Table 1.

\section{Table 2. The income of Farmers in Each Marketing}

Source: Data Processing Results

\begin{tabular}{|l|l|l|}
\hline Marketing & Male calf (Rp.- / tails) & Female calf (Rp. - / Tail) \\
\hline I & 5.700 .000 & 2.900 .000 \\
\hline II & 5.200 .000 & 3.500 .000 \\
\hline III & 5.700 .000 & 2.900 .000 \\
\hline IV & 6.842 .500 & 3.717 .500 \\
\hline
\end{tabular}

\section{Information}

I.
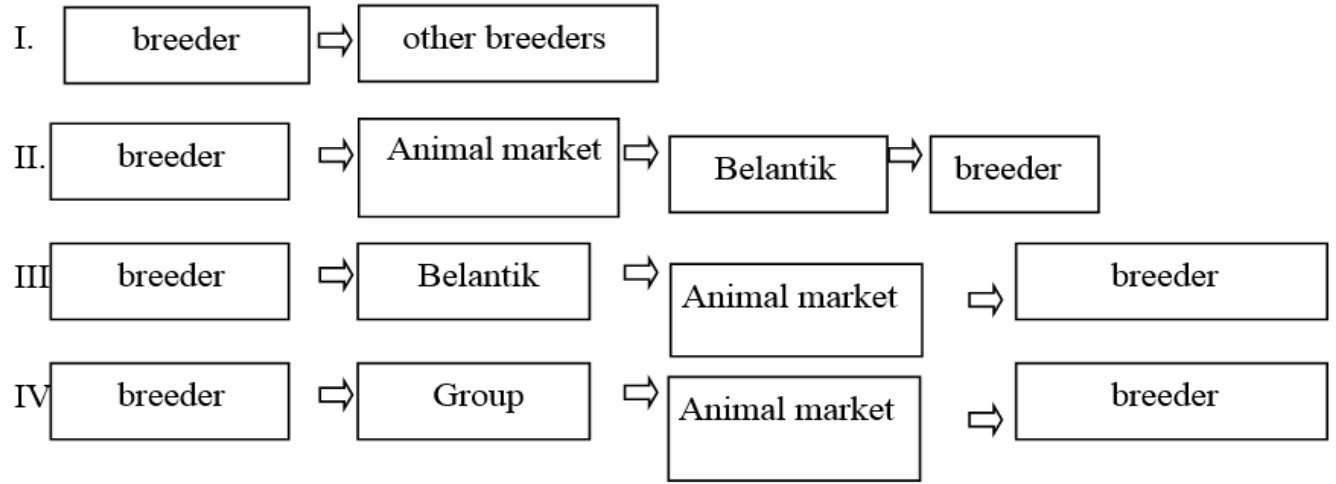

\section{Figure 2. Bali cattle calf marketing channel}

The price difference between male and female calf that almost doubled greatly affected the income of farmers. To increase farmers' income from calf marketing, the government should allow selling calf outside Bali, so calf prices can increase [22]. With the increase in calf prices will automatically be able to increase farmers' income. As shown in Table. 1 that the number of productive females in 2014 was 193,911. Means every year the chance of a female calf birth from community farms is 96,956 tails. On the other hand the government prohibits selling calf between islands, so that female calf production is high, while breeders' interest in maintaining low calf 
will have an impact on the low calf selling price as well. So that the income of farmers from female calf marketing will below as shown in Figure 3.

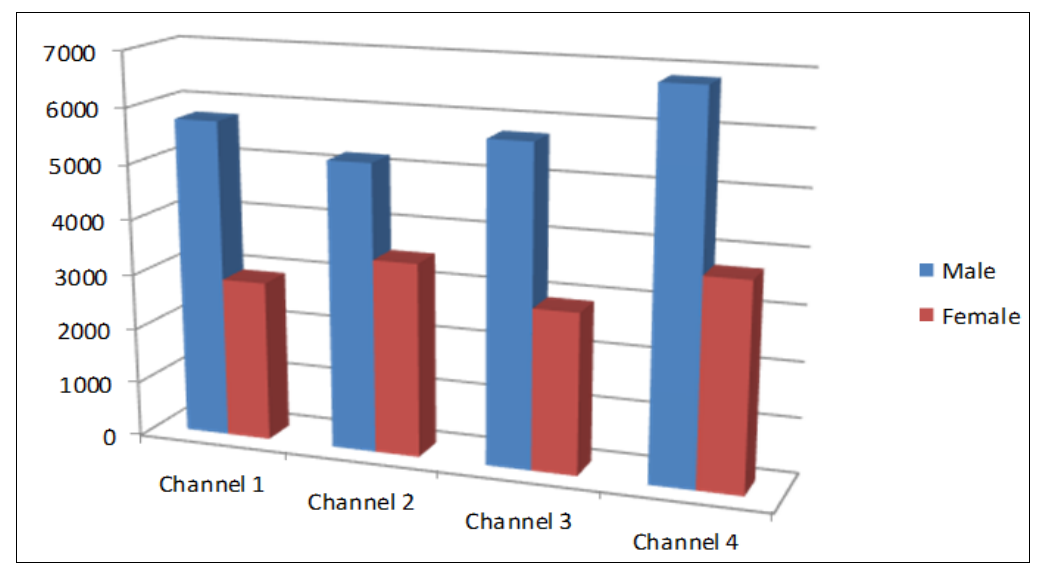

\section{Figure 3. Farmer Income in Each Marketing Channel}

Based on the amount of revenue from calf marketing, the average net income from calf marketing is $\mathrm{Rp}$ $4,557,500$ per year per breeder. This income compared to working hours used for livestock business in a year is 728 per hour. This means that farmers' income is still below the regional minimum wage for farming in the province of Bali, which is Rp. 1,900,000 per day (8 working hours) (Ministry of Manpower of Bali Province 2014) besides that this is because the calf maintenance period is only 8 months. So that farmers do not lose the breeders should keep more than one cow and extended investment life, so that this income reduction can be reduced because raising one to three cattle requires almost the same maintenance (labor used, equipment, and cost of the cage). This is supported by the research of [10], where to raise 3-4 cattle, it takes 2 hours per day. Income from other livestock farming activities besides mother cows is considered to be absent with the consideration that some farmers have very small amounts of chicken, ducks, pigs, and pigeons. Receipt from the sale of eggs is very small or even almost non-existent because it does not function routinely, the results of existing products are only for self-consumption so in this calculation are ignored.

\section{CONCLUSION}

The results of this study indicate that there are four channels formed by the calf marketing system in Bali, namely marketing channel I (breeder to other breeders 12\%), marketing channel II (breeder - animal market intermediary trader 10\%), marketing channel III (breeder - intermediary traders - animal market 73\%), and channel IV (breeders - group 5\%). Farmer income from the sale of calves through marketing IV that provides the highest income for both male and female calves is Rp 6,842,500 and $\mathrm{Rp} 3,717,500$.

\section{ACKNOWLEDGMENTS}

We would like to thank the Dean of the Faculty of Agriculture at Warmadewa University for facilitating. 


\section{REFERENCES}

Nazaruddin R (2011). Analisis strategi pemasaran peternakan ayam CV intan jaya abadi Sukabumi. Manajemen IKM: Jurnal Manajemen Pengembangan Industri Kecil Menengah 6(2): 64-73.

Tampubolon PF, Siregar H, Machfud M (2011). Strategi pengembangan usaha sapi perah skala mikro berwawasan lingkungan di Kabupaten Subang, Jawa Barat. MANAJEMEN IKM: Jurnal Manajemen Pengembangan Industri Kecil Menengah 6(2): 37-43.

Santosa U (1997). Prospek agribisnis penggemukan pedet. Penebar Swadaya.

Singarimbun M (1989). Metode dan Proses Penelitian” dalam Masri Singarimbun dan Sofian Effendi. Metode Penelitian Survey, Jakarta: LP3S.

Statistik BP (2014). Provinsi Bali dalam Angka. Bali: BPS.

Nazir M (1988). Metode Penelitian, Ghalia Indonesia.

Putri BRT (2014). Strategi manajemen usaha dan sistem agribisnis perbibitan sapi Bali untuk meningkatkan pendapatan peternak. Disertasi Program Pascasarjana Universitas Udayana, Bali.

Soekartawi S (1993). E-Agribisnis: Teori Dan Aplikasinya. Jurnal Fakultas Hukum UII.

Astiti NMAGR, Suparta IN, Oka L, Gusti I, Antara I (2016). Marketing systems of calf Bali. International Research Journal of Engineering, IT \& Scientific Research (IRJEIS) 2(11): 73-80.

Priyanto D (2016). Strategi pengembangan usaha ternak sapi potong dalam mendukung program swasembada daging sapi dan kerbau tahun 2014. Jurnal Litbang Pertanian 30(3): 108-116.

Astiti NMAGR, Mardewi NK (2006). Motivasi peternak dalam menghasilkan dan memasarkan pedet sapi bali di bali. Tata Kelola Lingkungan Kepariwisataan Menuju Desa Wisata Berbasis Kearifan Lokal: 13-19.

Sriyani N, Siti W, Suarta G, Partama IBG, Ariana NT, Yupardhi WS (2018). Responses of corncob as replacement of elephant grass on performance and carcass profile of Bali cattle. International Journal of Life Sciences 2(1): 42-49.

Sukada IK, Suarta IG, Parimartha INW (2016). The analysis of ruminant cattle potential as a source of meat production in east nusa tenggara regency. International Research Journal of Engineering, IT \& Scientific Research 2(5): 1-6.

Suryani NN, Suarna IW, Sarini NP, Mahardika IG (2017). Increasing energy ration of Bali cattle to improve digestible nutrient, milk yield and milk quality. International Research Journal of Engineering, IT \& Scientific Research 3(1): 8-17.

Miwada INS, Sumadi IK, Wrasiati LP, Sutama INS (2018). Gelatin characteristics of Bali cattle skin protein extract on acetic acid concentration and different length of curing. International Journal of Life Sciences 2(2): $12-21$.

Astiti NMAGR, Suparta, IN, Oka, L, Gusti, I, Antara I (2016). Marketing systems of calf Bali. International Research Journal of Engineering, IT \& Scientific Research (IRJEIS) 2(11): 73-80. 
Sio S, Mahardika I, Partama I, Suryani N (2016). Performance of Bali cattle that given of lannea coromandelica bark boiled as feed additive. International Research Journal of Engineering, IT \& Scientific Research, 2(7): 42-50.

Sio S, Sikone HY, Usboko CA (2018). Nutrient digestion and body weight gain of Balinese cows getting basic ration of spear grass and rosewood leaves supplemented with falcata tree leaves. International Journal of Life Sciences 2(2): 1-11.

Karnata IN, Putra AAG (2017). Improving products of vegetable types in dryland on potatoes compost waste basis and cattle rumen. International Research Journal of Engineering, IT \& Scientific Research 3(2): 50-58.

Mardewi NK, Astiti NMAGR, Rukmini NKS, Rejeki IGADS, Tonga Y, Suwitari, NKE (2017). Supplementation of moringa (moringa oliefera) powder into ration in increasing the quality of broiler's meat. International research journal of engineering, IT \& scientific research 3(3): 31-44.

Muliarta IN (2016). The evaluation of implementation of integrated farming system program and the reality of increasing farmers income in Bali. International Research Journal of Engineering, IT \& Scientific Research 2(7): 108-114.

Astiti NMAGR, Rukmini NKS, Rejeki IGADS, Balia RL (2019). The farmer socio-economic profile and marketing channel of bali-calf at bali province. Series "management, economic engineering in agriculture and rural development 19(1): 47-51. 